\title{
Hubungan Kadar Interleukin 10 Serum dan Klasifikasi CT Marshall pada Pasien Cedera Otak Berat akibat Trauma
}

\author{
${ }^{1}$ Melina O. Kurniawan, ${ }^{2}$ Eko Prasetyo, ${ }^{2}$ Maximillian Ch. Oley \\ ${ }^{1}$ PPDS Ilmu Bedah Fakultas Kedokteran Universitas Sam Ratulangi Manado \\ ${ }^{2}$ Divisi Bedah Saraf Bagian Ilmu Bedah Universitas Sam Ratulangi/RSUP Prof. Dr. R. D. \\ Kandou Manado \\ Email: melinaoktaviakurniawan@gmail.com
}

\begin{abstract}
Increased level of interleukin 10 (IL 10) in patients with severe traumatic brain injury (TBI) has been documented, yet studies of its ability to predict the outcome based on the Marshall CT classification are still limited and lacks of clarity. This study was aimed to evaluate the relationship between serum level of IL 10 and the Marshall CT classification among patients with severe TBI. This was an analytical observational single-center study with a cross-sectional design. Immediate CT scans were used to determine the Marshall CT classification and to categorize the location (extra-axial, intra-axial, both), hemisphere (midline/diffuse, dextral, sinistral), and area (frontal, parietal, temporal, occipital, multiple) of the injury. Venous blood sample for IL 10 was taken less than 24 hours of trauma in the Intensive Care Unit. Age and gender were also recorded. Variable selection was run in stepwise forward fashion. Proportional odds models were conducted to assess the changes in the Marshall CT classification related to levels of IL 10. There were 25 patients admitted consecutively to the emergency room (ER) with severe TBI included in this study. The results showed that the mean IL 10 was $107.3 \mathrm{pg} / \mathrm{ml}$ (SD $16.2 \mathrm{pg} / \mathrm{ml}$ ). Patients were distributed almost uniformly within four detected categories (diffuse injury II, III, V, and VI) of the CT Marshall classification. Final regression model consisted of IL 10, age, and injury on temporal area as predictors. Controlling for the others, every $10 \mathrm{pg} / \mathrm{ml}$ additional of IL 10 increased the odds to higher (worse) categories in the CT Marshall classification by about 1.95 (95\% CI $1.16-3.30$ ) times. Conclusion: Interleukin 10 is a potential predictor for the CT Marshall classification in patients with severe TBI.
\end{abstract}

Keywords: IL 10, Marshall CT classification, TBI

\begin{abstract}
Abstrak: Peningkatan kadar serum interleukin 10 (IL 10) pada pasien dengan cedera otak traumatik (COT) berat telah didokumentasikan, namun studi tentang kemampuannya untuk memrediksi hasil berdasarkan klasifikasi CT Marshall masih terbatas dan belum jelas. Penelitian ini bertujuan untuk mengevaluasi hubungan antara kadar serum IL 10 dan klasifikasi CT Marshall pada pasien COT berat. Jenis penelitian ialah observasional analitik dengan desain potong lintang. CT scan digunakan untuk menentukan klasifikasi CT Marshall dan untuk mengategorikan lokasi (ekstra-aksial, intra-aksial, keduanya), hemisfer (garis tengah/ difus, dekstra, sinistra), dan area (frontal, parietal, temporal, oksipital, multipel) otak yang terkena cedera. Sampel darah vena untuk IL 10 diambil kurang dari 24 jam pasca trauma. Usia dan jenis kelamin juga dicatat. Seleksi variabel dilakukan secara bertahap. Digunakan model regresi proporsional odds untuk menilai perubahan klasifikasi CT Marshall terkait dengan kadar IL 10. Hasil penelitian mendapatkan 25 pasien dengan COT berat yang masuk ke Instalasi Rawat Darurat Bedah (IRDB). Rerata IL 10 ialah $107,3 \mathrm{pg} / \mathrm{ml}$ (SD 16,2 pg/ml). Pasien didistribusikan hampir seragam dalam empat kategori (cedera difus II, III, V, dan VI) dari klasifikasi CT Marshall. Model regresi akhir terdiri dari IL 10, usia, dan cedera pada area temporal sebagai prediktor. Sebagai kontrol, setiap peningkatan IL 10 sebanyak $10 \mathrm{pg} / \mathrm{ml}$ meningkatkan kemungkinan klasifikasi CT Marshall yang lebih tinggi (lebih buruk) sekitar 1,95 (95\% CI 1,16-3,30) kali lebih tinggi. Simpulan: IL10 merupakan prediktor potensial untuk klasifikasi CT Marshall pada pasien dengan COT berat.
\end{abstract}

Kata kunci: IL 10, klasifikasi CT Marshall, COT 
Cedera otak traumatik (COT) adalah disfungsi otak sementara atau permanen, yang terjadi akibat gerakan kepala dan/atau tumbukan antara kepala dengan benda atau permukaan yang menyebabkan beban berlebih ke otak. ${ }^{1}$ Cedera otak traumatik merupakan penyebab terbanyak kematian dan kecacatan, ${ }^{2}$ dan semakin meningkat seiring dengan berkembangnya teknologi transportasi. ${ }^{3}$ Tingkat keparahannya tergantung pada mekanisme cedera dan akibat dari cedera otak sekunder. ${ }^{4}$ Di Inggris didapatkan 1,4 juta pasien per tahun dirawat di rumah sakit akibat $\mathrm{COT}^{2} \mathrm{Di}$ Indonesia menurut Riskesdas tahun 2007 dilaporkan prevalensi COT mencapai $16,4 \%$, yang merupakan cedera terbanyak kedua dari seluruh prevalensi cedera berdasarkan bagian tubuh. ${ }^{5}$

Interleukin 10 (IL-10) dikenal sebagai sitokin anti-inflamasi yang menggunakan sejumlah besar fungsi imunomodulator selama respons inflamasi dan penting dalam fase resolusi. Ekspresi IL-10 di otak meningkat pada keadaan patologi sistem saraf pusat, dan berfungsi meningkatkan kelangsungan hidup sel neuronal dan glial, serta mengurangi respons inflamasi. Selain itu, IL-10 sebagai faktor penghambat sintesis sitokin dan sebagai tambahan mengurangi sintesis sitokin proinflamasi. IL 10 juga membatasi peradangan dengan mengurangi ekspresi reseptor sitokin dan aktivasi reseptor penghambat. ${ }^{6}$ IL-10 berpengaruh terhadap sel-sel hematopoetik yang meningkat sesudah COT. Dalam hal ini IL-10 mengurangi fungsi aktivasi dan efektor sel $\mathrm{T}$, monosit, dan makrofag sehingga mengurangi respons inflamasi cedera. $^{\text {? }}$

CT scan merupakan prosedur pilihan yang sering dipakai, terutama untuk diagnosis, evaluasi, dan perkiraan progno-sis pasien dengan COT. Pada tahun 1991, Marshall et $\mathrm{al}^{8}$ mengelompokkan pasien COT menurut beberapa karateristik CT, dengan menggabungkan sifat anatomi cedera otak. CT Marshall menggunakan temuan dari CT scan pada tingkat mesensefalik, tingkat pergeseran garis tengah (midline), dan ada tidaknya lesi lokal serta lesi yang dapat dievakuasi atau tidak. ${ }^{8}$

Penelitian ini bertujuan untuk menilai hubungan kadar IL-10 serum dengan klasifikasi CT Marshall pada pasien COT berat agar dapat membantu para klinisi untuk mendapatkan korelasi dan pemahaman yang lebih baik tentang IL 10 dan CT Marshall sehingga dapat menentukan prognosis dan meningkatkan penanganan kasus COT berat di rumah sakit.

\section{METODE PENELITIAN}

Penelitian ini merupakan suatu studi analitik observasional dengan desain potong lintang. Subyek penelitian sebanyak 25 pasien COT berat yang masuk ke IRDB RSUP Prof. Dr. R. D. Kandou Manado sejak bulan Maret sampai Juni 2018 dengan kriteria inklusi onset trauma kurang dari 24 jam, usia 16-45 tahun, dan COT dengan GCS 3-8. Kriteria eksklusi ialah memiliki riwayat COT sebelumnya, mengidap penyakit infeksi/sistemik yang dapat mengganggu proses inflamasi, mengonsumsi obat atau zat yang dapat memengaruhi kesadaran atau inflamasi, atau dengan cedera penyerta lain.

Pasien dilakukan pemeriksaan CT scan kepala, kemudian dikelompokkan berdasarkan klasifikasi CT Marshall dan berdasarkan lokasi (ekstra-aksial, intra-aksial, keduanya), hemisfer (garis tengah/difus, dekstra, sinistra), dan area (frontal, parietal, temporal, oksipital, multipel) otak yang terkena dalam cedera. Kadar serum IL 10 diambil dari sampel darah vena dalam waktu kurang dari 24 jam post trauma.

Data diolah menggunakan fasilitas Microsoft Excel dan software statistik $\mathrm{R}$ versi 3.4.4. Analisis deskriptif untuk melihat distribusi variabel penelitian dilakukan secara univariat maupun bivariat. Perbedaan variabel menurut jenis kelamin diuji menggunakan uji t ataupun MannWhitney U untuk variabel numerik, dan uji Fisher's Exact untuk variabel kategorial. Model untuk klasifikasi CT Marshall menggunakan regresi proportional odds dengan kadar serum IL 10 sebagai faktor risiko utama. Hasil analisis regresi disajikan sebagai nilai odds rasio (OR). 


\section{HASIL PENELITIAN}

Penelitian ini dilakukan di RSUP Prof. Dr. R. D. Kandou Manado sejak bulan Maret sampai Juni 2018. Subyek penelitian sebanyak 25 orang penderita COT berat yang masuk dan dirawat di RSUP Prof. Dr. R. D. Kandou Manado serta memenuhi kriteria inklusi dan eksklusi.

Subjek penelitian ini didominasi pria $(\mathrm{n}=21$, atau $84 \%)$ dengan median usia 31 (IQR 21, 43) tahun (Tabel 1). Tidak seluruh klasifikasi CT Marshall terdeteksi pada pasien-pasien ini, namun di antara kategori yang ada (II, III, V, dan VI) proporsinya relatif uniform; berturut-turut, $28 \%, 28 \%$, $20 \%$, dan 24\%. Pemeriksaan CT scan menunjukkan bahwa cedera kepala para subjek terutama berlokasi di sekitar epidural, subaraknoid, ataupun subdural (n
$=15$, atau $60 \%$ ), dengan 10 orang lainnya (40\%) mengalami perdarahan dalam otak ataupun kombinasi ekstra-aksial dan intraaksial. Hampir sebagian (48\%) pasien mengalami cedera pada hemisfer dextra. Dalam hal daerah kepala yang terlibat, kebanyakan cedera mengenai area temporalis walaupun ada sejumlah individu mengalaminya pada beberapa area sekaligus. Pemeriksaan laboratorium memperlihatkan rerata kadar serum IL 10 setinggi $107,3 \mathrm{pg} / \mathrm{mL}$ (SD 16,2 pg/mL).

Hasil klasifikasi CT Marshall cukup bervariasi pada para subjek bila dilihat dari karakteristiknya (Gambar 1). Berdasarkan lokasi perdarahan, penderita dengan perdarahan ekstra-aksial memiliki keempat kategori dari klasifikasi CT Marshall yang ditemui dalam penelitian (II, III, V dan VI),

Tabel 1. Karaketristik Subjek Penelitian Menurut Jenis Kelamin, dalam Mean \pm SD, Median (Q1,Q3), ataupun $\mathrm{n}(\%)$

\begin{tabular}{lcccc}
\hline \multicolumn{1}{c}{ Karakteristik } & $\begin{array}{c}\text { Total } \\
\mathrm{N}=25\end{array}$ & $\begin{array}{c}\text { Laki-laki } \\
\mathrm{n}=4\end{array}$ & $\begin{array}{c}\text { Perempuan } \\
\mathrm{n}=21\end{array}$ & $\boldsymbol{P}^{\boldsymbol{a}}$ \\
\hline Usia (tahun) & $31(21,43)$ & $35(25,45)$ & $31(19,41)$ & 0,457 \\
Lokasi perdarahan & ${ }^{b}$ & & & \\
$\quad$ Ekstra-aksial & $15(60 \%)$ & $4(100 \%)$ & $11(52 \%)$ & 0,347 \\
Intra-aksial & $8(32 \%)$ & $0(0 \%)$ & $8(38 \%)$ & \\
$\quad$ Kombinasi & $2(8 \%)$ & $0(0 \%)$ & $2(10 \%)$ & \\
Hemisfer yang terlibat ${ }^{b}$ & & & & \\
Garis tengah/difus & $6(24 \%)$ & $3(75 \%)$ & $3(14 \%)$ & 0,015 \\
Dekstra & $12(48 \%)$ & $0(0 \%)$ & $12(57 \%)$ & \\
Sinistra & $7(28 \%)$ & $1(25 \%)$ & $6(29 \%)$ & \\
Area cedera ${ }^{b}$ & & & & \\
Frontalis & $6(24 \%)$ & $0(0 \%)$ & $6(29 \%)$ & 0,540 \\
Temporalis & $11(44 \%)$ & $1(25 \%)$ & $10(48 \%)$ & 0,604 \\
Parietalis & $8(32 \%)$ & $1(25 \%)$ & $7(33 \%)$ & $>0,100$ \\
Osipitalis & $6(24 \%)$ & $3(75 \%)$ & $3(14 \%)$ & 0,031 \\
Multipel & $7(28 \%)$ & $1(25 \%)$ & $6(29 \%)$ & $>0,100$ \\
IL 10, pg/mL & $107,3 \pm 16,2$ & $104,5 \pm 13,0$ & $107,9 \pm 17,0$ & 0,714 \\
Klasifikasi CT Marshall & & & & \\
Kategori I & $7(28 \%)$ & $2(50 \%)$ & $5(24 \%)$ & 0,714 \\
Kategori III & $7(28 \%)$ & $1(25 \%)$ & $6(29 \%)$ & \\
Kategori V & $5(20 \%)$ & $1(25 \%)$ & $4(19 \%)$ & \\
Kategori VI & $6(24 \%)$ & $0(0 \%)$ & $6(29 \%)$ & \\
\hline
\end{tabular}

${ }^{a}$ Nilai $P$ perbandingan laki-laki vs perempuan: untuk variabel numerik menggunakan uji $\mathrm{t}$ bila distribusi variabel normal dan uji Mann-Whitney U jika sebaliknya. Untuk variabel kategori menggunakan uji Fisher's Exact. ${ }^{b}$ Berdasarkan hasil CT Scan. 
sedangkan pasien dengan perdarahan kombinasi intraaksial dan ekstra-aksial hanya terdiri dari pasien pada kategori II dan V.

Bila dilihat dari hemisfer otak yang terlibat, pasien dengan perdarahan di sisi kiri kebanyakan $(57 \%)$ berada pada cedera difus III klasifikasi CT Marshall, sedangkan pasien dengan perdarahan di sisi kanan memiliki keempat kategori CT Marshall relatif merata. Perdarahan pada area frontalis dan oksipitalis cenderung menempatkan penderita pada kategori rendah (II dan III), sedangkan sekitar $63 \%$ pasien yang mengalami perdarahan pada area temporalis berada pada kategori V dan VI klasifikasi CT Marshall.

Gambar 2 menunjukkan kecenderungan hubungan terbalik antara usia dan keparahan kondisi pasien menurut klasifi- kasi CT Marshall. Median usia penderita dengan kategori tinggi (kondisi akibat cedera lebih buruk) terlihat lebih muda daripada mereka di kategori rendah yang kondisinya relatif kurang buruk.

Hasil analisis memperlihatkan distribusi univariat dari IL 10 yang cukup normal $(P>0,05$ menurut uji ShapiroWilk), dengan rerata 107,3 pg/mL (SD 16,2 $\mathrm{pg} / \mathrm{mL}$ ). Gambar 3 menyajikan grafik bivariat antara kadar serum interleukin 10 dan kategori dalam klasifikasi CT Marshall yang ada di antara subjek penelitian. Median IL 10 dari setiap kotak gambar tersebut menunjukkan kecenderungan kadar serum IL 10 yang lebih tinggi pada kategori yang lebih buruk. Hasil uji korelasi Spearman Rank atas kedua variabel ini memperlihatkan hubungan positif yang hampir bermakna $(\rho=0,34 ; p=0,096)$.
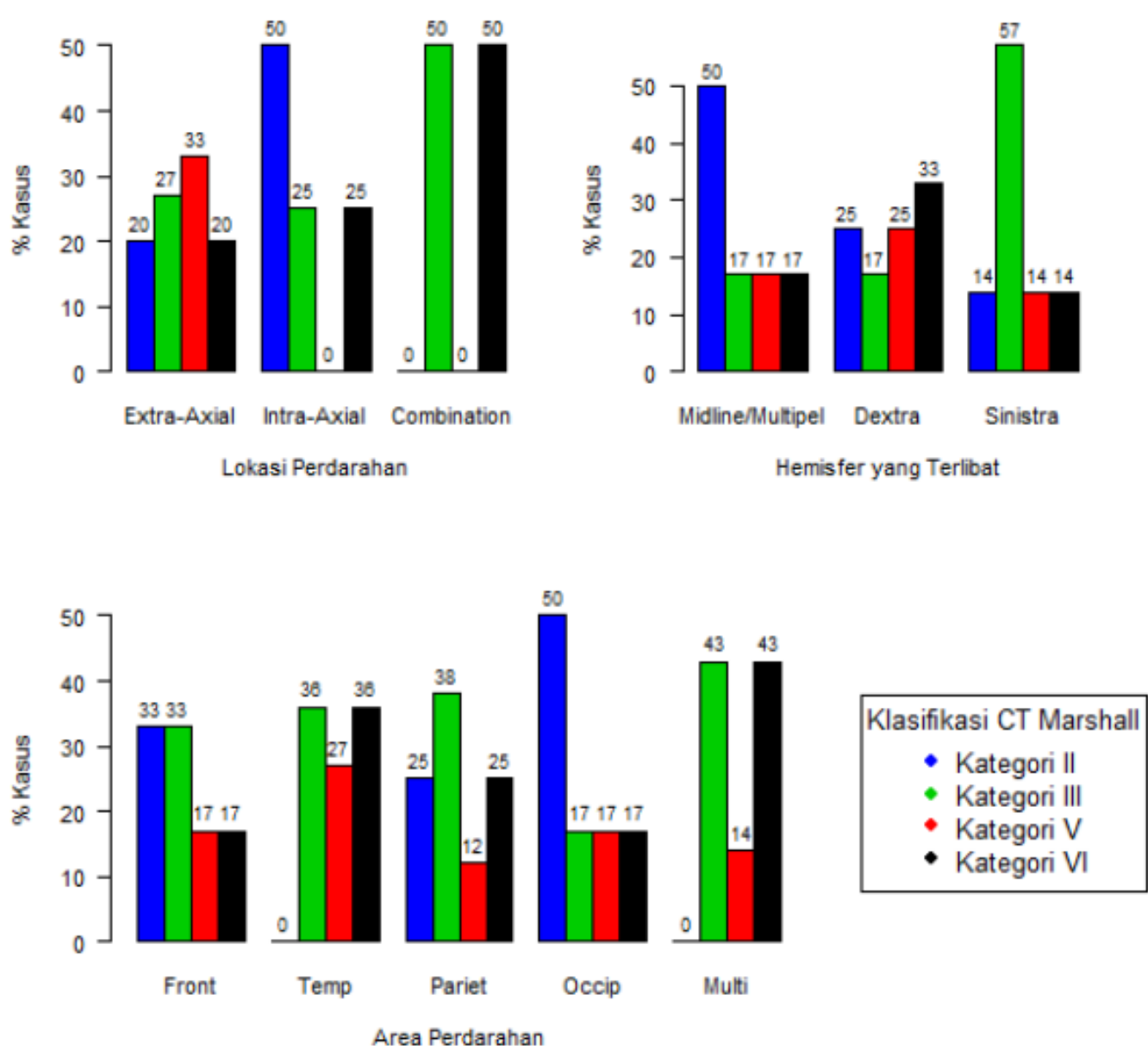

Gambar 1. Distribusi Kategori CT Marshall Menurut Hasil CT Scan 


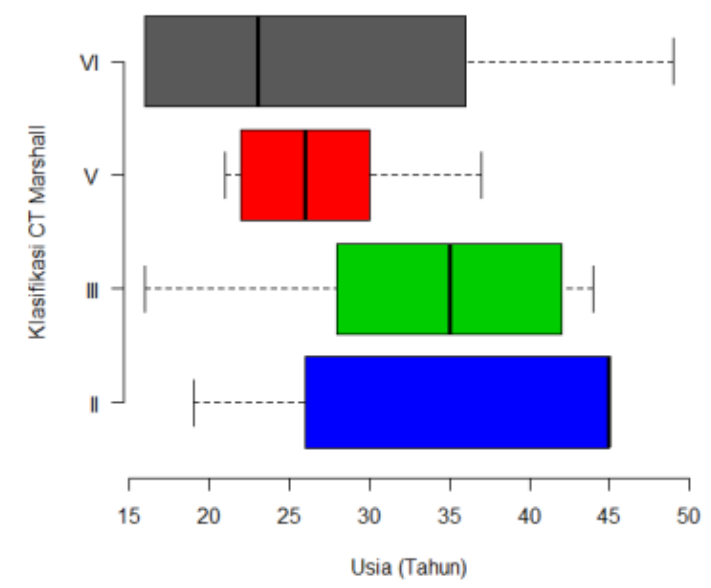

Gambar 2. Distribusi kategori CT Marshall menurut usia
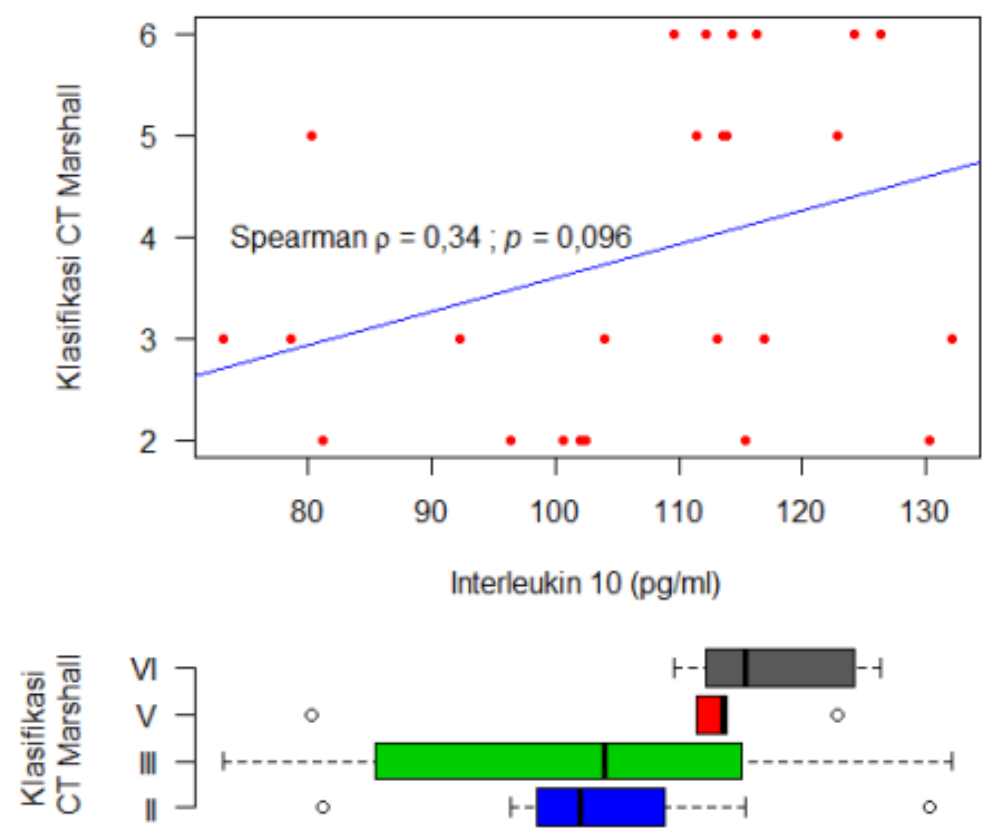

Gambar 3. Hubungan antara IL-10 dan kategori CT Marshall

Hasil analisis multivariat hubungan kadar IL 10 serum dan kategori cedera kepala pasien menurut klasifikasi CT Marshall disajikan pada Tabel 2. Hal ini dimaksudkan untuk memberi gambaran variabel-variabel yang berpotensi merancu hubungan IL 10 dengan klasifikasi CT Marshall. Cedera pada daerah temporalis memiliki hubungan bermakna dengan klasifikasi CT Marshall $(P=0,018)$.

\section{BAHASAN}

Subjek penelitian ini didominasi oleh laki-laki $(\mathrm{n}=21$, atau $84 \%$ ) dengan median usia 31 tahun. Data ini sesuai dengan berbagai studi sebelumnya, yang menyatakan COT didominasi oleh laki-laki usia muda. Tidak seluruh klasifikasi CT Marshall terdeteksi pada pasien-pasien ini, namun di antara kategori yang ada (II, III, V, dan VI) proporsinya relatif uniform, yaitu berturutturut, $28 \%, 28 \%, 20 \%$, dan $24 \%$. Temuan ini agak berbeda dengan penelitian MataMbemba et $\mathrm{al}^{9}$ yang justru mendapatkan distribusi CT Marshall terba-nyak berada di kategori 1 dan 2 (53,9\% dan 27,4\%). Perbedaan ini dapat disebabkan karena populasi subjek penelitian yang berbeda. 
Tabel 2. Model proporsional odds klasifikasi CT Marshall dengan kadar serum interleukin 10 sebagai faktor risiko utama

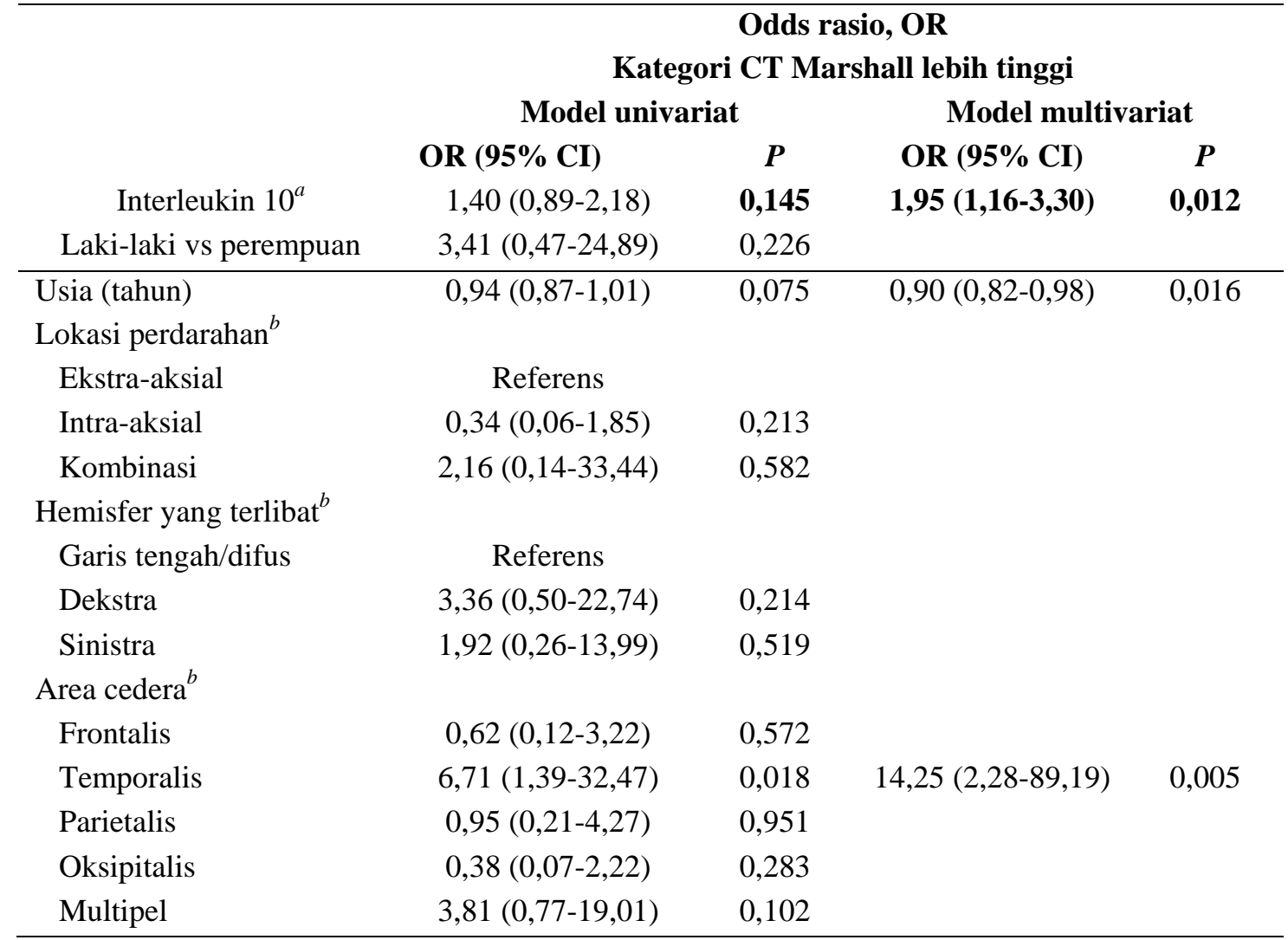

CI confidence interval; ${ }^{a}$ Setiap kenaikan $10 \mathrm{pg} / \mathrm{mL} ;{ }^{b}$ Berdasarkan hasil CT scan

Pada penelitian ini hanya diambil pasien dengan COT berat sedangkan penelitian Mata-Mbemba et $\mathrm{al}^{9}$ justru mempunyai populasi COT ringan yang besar $(62,8 \%)$.

Pemeriksaan CT scan menunjukkan bahwa cedera kepala para subjek terutama berlokasi di sekitar epidural, subaraknoid, ataupun subdural $(\mathrm{n}=15$, atau $60 \%)$, dengan 10 orang lainnya $(40 \%)$ mengalami perdarahan dalam otak ataupun kombinasi ekstra-aksial dan intra-aksial. Sebagian pasien (48\%) mengalami cedera pada hemisfer dekstra. Dalam hal daerah kepala yang terlibat, kebanyakan cedera mengenai area temporalis walaupun terdapat sejumlah pasien mengalaminya pada beberapa area sekaligus (seperti frontoparietal atau temporoparietal). Hasil penelitian ini memperlihatkan rerata kadar IL-10 serum setinggi 107,3 pg/mL (SD 16,2 pg/mL). Kadar serum yang berbeda dilaporkan oleh Csuka et $\mathrm{al}^{10}$ yang mendapatkan rerata kadar IL-10 serum sebesar 5,4-23 pg/ml.
Csuka et $\mathrm{al}^{10}$ menggunakan sampel IL-10 sampai hari ke-22 sedangkan dalam penelitian ini sampel IL-10 diambil kurang dari 24 jam. Helmy et al $^{11}$ mendapatkan bahwa kadar plasma IL-10 dalam COT mencapai puncak dalam hari ke-5 dan -6. Hal ini diduga yang menyebabkan adanya perbedaan kadar IL-10 dalam kedua penelitian tersebut.

Berdasarkan data hasil penelitian dan analisis data didapatkan kadar IL-10 serum meningkat setelah terjadi COT, dengan rerata kadar IL-10 serum setinggi 107,3 $\mathrm{pg} / \mathrm{mL}$ (SD 16,2 pg/mL). Hal ini sesuai dengan yang telah didokumentasikan pada penelitian-penelitian sebelumnya, yaitu kadar IL 10 serum akan meningkat dalam 2 jam sampai 3 hari setelah trauma. ${ }^{12}$ Nilai kadar IL 10 serum akan semakin meningkat pada cedera yang lebih buruk ${ }^{12}$ yang pada penelitian ini dikategorikan berdasarkan klasifikasi CT Marshall.

Dari hasil analisis univariat hampir tak 
satupun variabel penelitian memiliki hubungan bermakna, kecuali variabel cedera pada daerah temporal $(P=0,018)$. Besar sampel yang terbatas dan variabel jenis kelamin sebagai variabel perancu yang tidak proporsional dapat berperan dalam hal ini. Namun setelah faktor-faktor tersebut ditahan konstan, ditemukan bahwa pasien rata-rata mengalami peningkatan odds untuk kategori CT Marshall lebih tinggi hampir dua kali lipat lebih besar $(95 \%$ CI $\quad 1,16-3,30 ; \quad P=0,012) \quad$ setiap peningkatan kadar serum IL 10 sebesar 10 pg/mL. Menurut Garcia et al, ${ }^{12}$ kadar IL 10 serum yang tinggi cenderung mengarah pada keluaran yang lebih buruk setelah COT, sehingga IL 10 dapat dijadikan sebagai nilai prognostik.

\section{SIMPULAN}

Terdapat hubungan antara kadar IL-10 serum dengan klasifikasi CT Marshall. Semakin tinggi kadar IL-10 maka klasifikasi CT Marshall semakin buruk. Oleh karena itu IL-10 maupun CT Marshall dapat menjadi prediktor potensial untuk menentukan tingkat keparahan serta prognosis pada pasien dengan COT.

\section{SARAN}

Perlu dilakukan penelitian lanjutan dengan jumlah sampel yang lebih besar dan perbandingan jumlah jenis kelamin yang proporsional. Hubungan kadar serum IL-10 dengan keluaran pasien COT baik awal maupun jangka panjang juga harus dievaluasi lebih lanjut.

\section{DAFTAR PUSTAKA}

1. La Placa MC. Manual of Traumatic Barin Injury. Essential Concepts in TBI Biomechanics and Neuropathology (2nd ed). New York: Demos Medical, 2016; p. 10-7.

2. Lawrence T, Helmy A, Bouamra O, et al. Traumatic brain injury in England and Wales: prospective audit of epidemiology, complications and standardised mortality. BMJ open. 2016;6(11):1-8.

3. Irawan H, Setiawan F, Dewanto G.
Perbandingan Glasgow coma scale dan revised trauma score dalam memprediksi disabilitas pasien trauma kepala di Rumah Sakit Atma Jaya. MKI. 2010;60(10):437-42

4. Schneider Soares FM, de Souza NM, Schwarzbold ML, Paim DA, Nunes CJ, Hohl A, et al. Interleukin-10 is an independent biomarker of severe traumatic brain injury prognosis. Neuroimmunomodulation. 2012;19(6): $377-85$.

5. Riyadina W, Suhardi PM. The pattern and sociodemographic determinant of traffic injury in Indonesia. MKI. 2009; 59 (10):464-72.

6. Strle K, Zhou JH, Shen WH, Broussard SR, Johnson EW, Freund GG, et al. Interleukin-10 in the brain. Crit Rev Immunol. 2001;21(5):427-49.

7. Moore KW, de Waal MR, Coffman RL, O'Garra A. Interleukin-10 and the interleukin-10 receptor. Annu Rev Immunol. 2001;19(1):683-765.

8. Zhu GW, Wang F, Liu WG. Classification and prediction of outcome in traumatic brain injury based on computed tomographic imaging. J Int Med Res. 2009;37(4):983-95.

9. Mata-Mbemba D, Mugikura S, Nakagawa A, Murata T, Ishii K, Li L, et al. Early CT findings to predict early death in patients with traumatic brain injury. Acad Radiol. 2014;21(5):605-11.

10. Csuka E, Morganti-Kossman MC, Lenzlinger PM, Joller $H$, Trentz $\mathbf{O}$, Kossmann T. IL-10 levels in cerebrospinal fluid and serum in patients with severe traumatic brain injury: relationship to IL-6, TNF-alpha, TGF-beta1 and blood-brain barrier function. $\mathbf{J}$ Neuroimmunol. 1999;101(2):211-21.

11. Helmy A, Antoniades CA, Guilfoyle MR, Carpenter KLH, Hutchinson PJ. Principal component analysis of the cytokine and chemokine response to human traumatic brain injury. Plos ONE. 2012;7(6):e39677.

12. Garcia JM, Stillings SA, Leclerc JL, Philips H, Edwards NJ, Robicsek SA, et al. Role of interleukin-10 in acute brain injury. Front Neurol. 2017;8 (244):1-17. 